\title{
IN VITRO CELLULAR MODELS, A RESOURCEFUL TOOL IN RESPIRATORY TOXICOLOGY
}

\author{
IONEL FIZESAN ${ }^{1}{ }^{1}$, SÉBASTIEN CAMBIER $^{2}$, ELISA MOSCHINI $^{2}$, ALINE CHARY $^{2}$, ANCA POP $^{1 *}$, \\ BÉLA KISS ${ }^{1}$, TOMMASO SERCHI ${ }^{2}$, ARNO C. GUTLEB $^{2}$, FELICIA LOGHIN $^{1}$ \\ ${ }^{I}$ Toxicology Department, "Iuliu Hațieganu” University of Medicine and Pharmacy, Faculty of Pharmacy, Cluj-Napoca, Romania \\ ${ }^{2}$ Environmental Research and Innovation (ERIN) Department, Luxembourg Institute of Science and Technology, Belvaux, \\ Luxembourg
}

*corresponding author: anca.pop@umfcluj.ro

Manuscript received: February 2018

\begin{abstract}
Due to the increasing concerns regarding the transferability of data from animal studies to potential human health effects, the development of complex in vitro cellular models which could potentially replace the ethically-debatable in vivo studies and fill the existing gap between in vivo and in vitro data has received considerable attention. The current review focuses on pulmonary in vitro cellular models available for studying the biological effects elicited by inhaled chemicals. The advantages and disadvantages of the 2D monoculture system and the more complex 3D models such as co-cultures and organ-on-a-chip platforms are discussed. Moreover, recent advancements in the field of respiratory toxicology such as the development of airliquid interface systems that better mimic the in vivo respiratory exposure are reviewed. We conclude with future perspectives of the in vitro cellular models in respiratory toxicology.
\end{abstract}

\section{Rezumat}

Transpunerea datelor toxicologice rezultate din studiile pe animale în posibile efecte la nivelul sănătății umane este problematică, mai ales din cauza diferențelor dintre specii. În acest context, a fost încurajată dezvoltarea unor modele celulare in vitro complexe care evită și unele restricții etice asociate cu studiile in vivo. Articolul de față se concentrează pe modelele celulare pulmonare in vitro disponibile pentru studierea efectelor biologice provocate de substanțele chimice inhalate. Sunt discutate avantajele și dezavantajele sistemelor de tip monocultură 2D, precum şi ale modelelor mai complexe, 3D (co-culturi organotipice, platforme "organ-on-a-chip"). Sunt amintite de asemenea cele mai recente progrese din domeniul toxicologiei respiratorii, cum ar fi dezvoltarea sistemelor de interfață aer-lichid care imită mai bine expunerea respiratorie in vivo, precum și perspective viitoare ale modelelor in vitro în toxicologia respiratorie.

Keywords: co-cultures, air-liquid interface, respiratory toxicology, lung

\section{Introduction}

Inhalation toxicology studies have been traditionally performed on animal models. However, difficulties regarding data transferability from in vivo studies into potential health impact on humans and the increasing concerns regarding the animal welfare have prompted the development of in vitro studies as alternatives [17]. In vitro model systems serve currently as a viable choice for toxicity screening of inhalable materials, as they are convenient, cost and time efficient. Although classical 2D monocultures of cells originating from specific regions of the respiratory tract do not reflect the complexity of the whole respiratory system, their usefulness in deciphering key aspects underlying physiological and pathophysiological processes in certain circumstances is undeniable. While for in vivo models it is almost impossible to improve their relevance because of the inherent differences between species, in vitro models using cell cultures are amendable for further improvements. In the last decades, complex in vitro models using differentiated primary cells, co-cultures of cells arranged in a 3D format on bio-engineered scaffolds and microfluidic systems have been developed, and hold the promise for a more thorough characterization of the potentially detrimental effects of inhalable compounds. Another important step for the improvement of in vitro models in respiratory toxicology was the development of exposure systems which allow the direct exposure to aerosols containing the inhalable material, thus closely mimicking native respiratory exposure. Moreover, in case of inhalable particles, the direct exposure of cells to the aerosol is even more important as the cellular uptake and subsequently their toxicity profiles can be considerably altered during conventional submerged exposure.

The aim of the current paper was to describe the possibilities available for studying the toxicity of inhalable toxicants using in vitro cell models. Advantages and limitations displayed by the current in vitro models are systematically discussed starting from the basic 
FARMACIA, 2018, Vol. 66, 4

2D monocultures and culminating with the state-ofthe-art organ-on-a-chip platforms. A special interest was manifested towards describing the high relevance of 3D co-culture systems and other advancements in the field of respiratory as these improvements hold the promise to fill in the gap between in vitro and in vivo data.

\section{Structure and function of the respiratory system}

Inhalation is the main route of exposure to airborne toxicants, whereby the respiratory system serves as the primary port of entry and as a primary target. The respiratory epithelium forms a physical barrier with tight junction (TJ) complexes which is directly in contact with the external environment, offering protection to the underlying tissue. Depending on the section of the human airway, different types of cells including mucus producing goblet cells, ciliated cells and non-ciliated cells are organized into a protective pseudo-stratified epithelium [28]. In the alveolar region, two types of cells namely alveolar type I and II cells (AEC1 and AEC2, respectively) form the cellular basis for the gas exchange membrane. AEC 1 cells cover up to $95 \%$ of the alveolar surface and due to their flatten morphology favour gas exchange processes, while AEC2 cells secrete the alveolar surfactant which prevents the alveolar collapse and can act as progenitor cells for AEC1 [18]. Besides this barrier function, epithelial cells are highly metabolic competent cells expressing an extended range of metabolic enzymes including the cytochrome P450 family and are able to metabolise inhaled toxicants [9]. At the tracheobronchial level, cilia and mucus act as a very efficient barrier for most of the inhaled toxicants, including particles by trapping and transporting them in the gastro-intestinal tract via the mucociliary escalator. In addition to the physical entrapment of foreign materials, mucus is also abundant in antibiotic factors such as antibiotic peptides and oxidizing enzymes which further act as defensive mechanisms [24]. In the more distal parts of the respiratory system cilia and mucus are not present, thus different humoral and cellular mechanisms of defence exist at the alveolar level. Humoral immunity is mainly mediated by pulmonary-surfactants A and D (SP-A, SP-D), lactoferrins, defensins and manose binding lectins, while cellular immunity is primarily mediated by alveolar macrophages (AM), recruited neutrophils and leukocytes [24]. AM play a key role in the initiation and the resolution of inflammatory processes, displaying a high plasticity and duality. Distinct micro-environmental cues can lead to differentiation of AM in subpopulations with antagonist effects such as cytotoxic/mitogenic, pro/ anti-inflammatory, or fibrinogenic activities [1].

Nevertheless, the above mentioned defence mechanisms can be overwhelmed by the exogenous toxicants, and loss of barrier function caused by cellular death and local inflammation due to the recruitment of immune cells can occur. Moreover, in chronic diseases such as asthma and chronic-obstructive pulmonary disease (COPD), changes in the epithelial differentiation and the mucus production are observed [47, 68].

\section{Required characteristics for cell culture models used in inhalation toxicology}

The primary role of in vitro cellular models is to reproduce the function and organization of the native biological systems, in this case the respiratory epithelium, either in healthy or disease state. Moreover, an appropriate in vitro model should describe as closely as possible the mechanisms causing airway injury under exposure to inhalable toxicants, or the repair mechanisms in the case of inhalable therapeutic agents. The selection of the appropriate in vitro cellular model depends on the compound of interest and how it may interact with the exposed in vivo system.

An in vitro model used to assess the respiratory translocation of an inhalable toxicant or a therapeutic agent into the general circulation or other inner tissues should be able to develop a relevant physical barrier with a polarized epithelium to properly assess the toxicological or therapeutic implications. This is also required when the mechanism of toxicity is suspected to be related to the loss of barrier integrity. In addition, the ability of the in vitro models to secrete respiratory fluids such as mucus or alveolar surfactant is of crucial interest, as these secretions are present in vivo and have been found to mitigate the toxicity or lower the bioavailability of toxicants and therapeutic agents, respectively [34]. Besides these defensive mechanisms, the metabolic competence of the in vitro models should be comparable with the one observed in vivo as numerous inhalable agents are known to be detoxified or bio-activated by metabolizing enzymes in the respiratory system [9].

Even though 2D classical monocultures of cells do not fulfil the above mentioned requirements, further improvements were continuously made to encompass the previously experienced limitations. One major limitation encountered in the classical submerged cultures is the method of exposure to the tested compound [56]. This way of exposure is different from the native exposure of respiratory epithelia which occurs at the air-liquid interface (ALI), and may change the outcome of the experiments [42]. Various ALI exposure systems have been developed and are currently recognized as better alternatives to submerged exposure in respiratory toxicology [42]. Co-cultivation of cells originating from epithelial, immune or endothelial lineages has allowed a proper cell-to-cell communication, which underlies complex processes such as inflammation and sensitization [38]. Moreover, complex cellular 3D models cultivated on 
FARMACIA, 2018, Vol. 66, 4

bio-engineered scaffolds or inserts allowing a $3 \mathrm{D}$ orientation have emerged and may pave the way for a better transferability of data into potential health effects [36, 44, 49].

\section{Types of epithelial cells used in respiratory toxicology}

\section{Primary epithelial cells}

Primary human respiratory epithelial (nasal, tracheobronchial and alveolar) cells can be directly isolated from human tissue by (a)traumatic techniques. In addition, fully differentiated in vitro models of the tracheobronchial and alveolar regions are available from commercial providers (EpiAirway $^{\mathrm{TM}}$ model from MatTek, MucilAir ${ }^{\mathrm{TM}}$ from Epithelix). The cultivation of isolated primary epithelial cells at the ALI on insert membranes leads to the development of a differentiated epithelium composed of both ciliated and mucus producing cells. For the propagation of cells, sub-merged conditions are well suited. By switching the cell culture to the ALI, the increased diffusion of oxygen is enhancing the cellular differentiation due to the accelerated oxidative cellular metabolism. Primary epithelial cells develop a tight physical barrier which is polarized and has a distinctive secretome in the apical and basolateral compartment when cultured on inserts [55]. Moreover, the metabolic activity of these differentiated models is similar to the one observed in vivo. When isolated from patients with chronic diseases such as asthma and COPD, primary cells maintain their disease phenotype, thus allowing experiments to be conducted on models for pathologic conditions $[12,39,43]$. This ability of primary epithelial cells to maintain their disease phenotype can be also useful for testing therapeutic agents for chronic respiratory diseases.

Even though cultured primary cells offer the closest resemblance to the native tissue in healthy and disease status, difficulties stemming from the isolation procedure and complex cultivation requirements, heterogeneity and high inter-donor variability and lastly their limited life span, hinder their use in toxicity assessment. Regarding the limited life span of isolated primary cells, recent advances in the field of conditionally reprogrammed cells have allowed the exponential growth of the isolated primary cells in the presence of a Rho-kinase inhibitor and of a feeder cellular layer without the need to alter the genome of the cells $[8,30]$.

\section{Cell lines}

Even though the continuous epithelial cell lines do not display the same capacity of differentiation as isolated primary cells, they have been used successfully in toxicological studies in certain circumstances. Cell lines originating from a single donor present a smaller heterogeneity than primary cells and are easier to cultivate. Moreover, due to their nature (immortalized or tumour origin) they have an extended life span, thus making large scale studies possible. Several cell lines representative for each section of the respiratory tract including nasal, bronchial and alveolar region are available and have been frequently used as models for the evaluation of airborne toxicants.

RPMI-2650 cell line (ATCC CCL30 ${ }^{\circledR}$ ) is the only available human nasal epithelium cell line at this moment. The cultivation at the ALI is the most critical requirement for reproducing in vivo like structures and properties $[5,40]$. Similar to in vivo nasal epithelia, RPMI-2650 is able to form a polarized epithelium with similar transepithelial electric resistance (TEER) values and well-developed TJs [21, 40]. Moreover, RPMI-2650 cells can produce a mucoid material and show a similar metabolic activity as normal nasal epithelium cells $[41,53]$. The major drawbacks of this cellular model arise from its low differentiation ability [64].

For tracheobronchial segment of the respiratory tract, three epithelial cell lines namely, Calu-3, BEAS-2B and $16 \mathrm{HBE} 14 \mathrm{o}-$ are routinely used. BEAS-2B cells retain a typical epithelial polygonal appearance with a normal anti-oxidant capacity, and a similar expression of genes involved in the metabolism of xenobiotics as observed in primary bronchial epithelial cells $[4,35$, 61]. They display a non-malignant phenotype, making them useful for studies of multistage bronchial epithelial carcinogenesis, with the p53 missense mutation having no impact on the functionality of this gene [51]. Similarly to other respiratory epithelial cell lines, the innate defence mechanisms represented by mucus secretion and mucus clearance are not present in BEAS-2B models as they do not display the differentiated epithelium observed in vivo $[19,66]$. The existing data regarding the capacity of this cell line to develop a tight polarized epithelium in submerged and ALI conditions are sparse, with TEER values below $100 \Omega / \mathrm{cm}^{2}$ and as high as $1000 \Omega / \mathrm{cm}^{2}$ being reported $[29,61,69]$.

$16 \mathrm{HBE} 14 \mathrm{o}-$ is an immortalized tracheal epithelial cell line transformed with the SV40 large antigen. This cell line maintains a differentiated epithelial phenotype characterized by a polarized epithelium with well-developed surface microvilli and cilia [70]. 16HBE140- cell line displays a similar response pattern as primary bronchial epithelial cells when challenged with various stimuli [2, 25]. Dissimilarities between 16HBE14o- and primary bronchial epithelial cells regarding the expression of genes involved in the xenobiotic metabolism were reported recently $[14,16]$. 16HBE14o- cells express high levels of TJ proteins, and under submerged conditions they develop a tight epithelial barrier with TEER values higher than $500 \Omega / \mathrm{cm}^{2}[45,59]$.

Calu-3 is a well characterized cell line which forms a tight epithelial barrier with high TEER values, being 
FARMACIA, 2018, Vol. 66, 4

routinely used to model the respiratory epithelial barrier in toxicology or drug delivery studies [22]. Cultured at ALI, Calu-3 cell line develops a functional epithelium with microvilli and secretes a mucoid material which incorporates mucins such as MUC5AC. Moreover, when cultivated over longer periods of time, a rugged appearance denoting a pseudostratified epithelium was obtained [60].

For the alveolar region of the respiratory tract the most used cell lines are A549 and NCI-H441. Even though A549 was considered and routinely used as a continuous cell line representative for AEC2, some controversy regarding the phenotype of this cell line still exists. In a recent study it was reported that the development of an AEC2 phenotype is dependent on the long term culture of A549 in an appropriate medium [13]. By Raman Spectral Phenotyping, A549 cells were found to be more similar in nature to AEC1 than AEC2 [62]. In addition to the uncertainty regarding the utility of A549 cells as surrogates for AEC2, a major difference between cultured A549 cells and primary AECs is the inability of the former ones to establish an epithelial barrier with high TEER values [11]. Several components of TJs such as zona-occludens, claudins and occludins were detected at transcriptional and translational level, but the high permeability and the low TEER values are indicative of defective TJs [11].

NCI-H441 cell line presents a cuboidal morphology with microvilli and cytoplasmic structures characteristic for AEC2 cells [20, 26, 27]. The expression of surfactant proteins (A-D) and thyroid transcription factor 1 (TTF-1), typical markers of AEC cells, were also reported in NCI-H441 [27]. Similarly to the in vivo alveolar epithelial barrier, NCI-H441 is able to form a polarized epithelium with strong TJs and TEER values up to $1000 \Omega / \mathrm{cm}^{2}[26,50,57]$. Despite the apparent advantages offered by NCI-H441 over the A549 cell line, the use of this cell line in respiratory toxicology studies is limited due to the slower growth rate.

Induced pluripotent stem cells

The use of stem cells as progenitors for primary lung epithelial cells was described in literature and may encompass the limited lifespan of isolated primary lung epithelial cells. The induced pluripotent stem cells (iPSC) directly generated from somatic cells by gene editing the four Yamanaka factors (Oct4, Sox2, cMyc and Klf4) into the cell-genome offers a convenient alternative to the ethically-debatable embryonic stem cells [63]. Similarly to embryonic stem cells, iPSC can be guided to differentiate into specific cell types including respiratory epithelium cells. Moreover, the use of iPSC made the generation of patient specific in vitro cultures possible and is a breakthrough in the field of personalized medicine [63]. The use of iPSC can offer an unlimited supply of patient specific pluripotent cells starting from somatic cells isolated through non-invasive (urine) and minimally-invasive (blood) techniques. However, the differentiation process is expensive and needs specific factors at specific time intervals, thus limiting the use of iPSC in toxicological assessments.

\section{Complex cellular models}

Traditionally, the cells of choice for studying the effects of inhalable toxicants were represented by epithelial cells as these cells are directly exposed to inhaled compounds. However, in the structure of respiratory epithelium, several types of cells communicate and elaborate the biological response to the external stimuli. Even though in vitro cell cultures will never achieve the complexity of the whole respiratory system, further improvements in the complexity of in vitro models are necessary to study more intricate processes such as inflammation and respiratory sensitization [38]. It should be emphasized that a compromise regarding the complexity of the in vitro models needs to be done as one of the main advantages of these models is their simplified nature which allows to better control possible variables and to use high throughput techniques. For the development of such models, porous membranes (inserts), which allow the cultivation of cells on both sides, are generally used. By selecting from the various pore sizes available, different models which limit or on the contrary, favour the contact between the different cell lineages is possible and further allows studying the type of communication between the different cell types (paracrine or direct cell-to-cell contact).

Based on these considerations, co-cultures of epithelial cells with other cell types including immune cells (differentiated macrophages, mast and dendritic cells), fibroblasts and endothelial cells have been developed to investigate the key pathophysiological mechanisms of toxicity behind inhaled toxicants [3, 26, 38, 44]. The establishment of co-cultures is not a trivial task, as each type of cells needs its own type of cellular media and supplements. Moreover, the ratio between the different cell types needs to mirror the in vivo situation in disease or normal status. Nevertheless, the establishment of co-cultures is still feasible as plentiful solutions do exist [38].

Besides the physical barrier provided, epithelial cells play a central role in the initiation and the resolution of inflammation processes as these cells are involved in the recruitment of immune cells at the inflammation site. This is considered to rely not only on the release of soluble cytokines and mediators, but also on the direct cell-to-cell contact. Due to the permanent exposure to various stimuli, AM are less prone to induce a strong pro-inflammatory response which could be detrimental to the organism. This self-modulatory effect was also replicated during in vitro co-cultivation of epithelial cells (A549) with macrophages (THP-1) 
FARMACIA, 2018, Vol. 66, 4

when the LPS-induced pro-inflammatory mediators were decreased in the co-culture system [58]. Moreover, the communication between epithelial and immune cells is bidirectional as several studies showed that epithelial cells co-cultivated with immune cells develop a more differentiated epithelium with higher TEER values and more abundant apical secretions (mucus or surfactant) [15]. The inclusion of immune cells in co-cultures offers the possibility to obtain in vitro models representative for healthy and diseased respiratory tissue. This was recently described for the development of two different alveolar models in healthy and disease status by incorporating the M1 (pro-inflammatory) and M2 (anti-inflammatory) subtypes of macrophages in a co-culture of epithelial and endothelial cells [33]. The development of co-cultures offers in addition the possibility to evaluate indirect effects on the underlying types of cells, mimicking thus the in vivo situation. Endothelial cells which form a layer under the respiratory epithelium are key players in the initiation of the pro-inflammatory response as they favours the recruitment of immune cells from the systemic circulation at the inflammatory site [37]. As both epithelial and endothelial cells communicate in order to propagate or resolve inflammatory processes, both cellular layers can be considered as one integral functional unit [10]. Moreover, endothelial cells have been shown to influence the growth and differentiation of epithelial cell line under no other stimuli [10]. Coculture of different endothelial and epithelial cells has been successfully used for the evaluation of inhalable toxicants, with the apical exposure of the epithelial side inducing an indirect response on the endothelial side propagating endothelial activation and dysfunction $[6,37,54]$.

The current studies which evaluated the response of co-cultures to inhalable toxicants indicate that cocultures better mimic the responses observed in vivo as the overall toxicity is lower, and the inflammation process is better preserved, most probably due to the presence of macrophages [3, 67]. Moreover, the genotoxic potential of particulate matter, inhalable particles resulting from combustion processes, has been shown to be lower in co-cultures, emphasizing the active role of macrophages in the defence against inhaled toxicants [32].

Even though commercially available porous membranes are accessible and convenient, in studies intended to evaluate the transport through the epithelial barrier, they can impede the transport of macromolecules or other physical entities such as nanoparticles or particles due to their thickness and pore size. To encompass this limitation, other kind of solid supports such as ultrathin porous silica membranes have been developed and can be used as an alternative [23]. Moreover, the use of inserts alone does not replicate the $3 \mathrm{D}$ architecture and the milieu formed by the extracellular matrix observed in vivo. Tissue engineered scaffolds based on polymers have emerged as a solution to the above mentioned limitation. If constructed properly, these scaffolds can incorporate in an architectural arrangement of extracellular matrix different cell populations, thus constructing an in vitro system similar to native micro-environments. An increased interest in using decellularized respiratory tissue of the tracheae or lungs for the development of more realistic 3D in vitro models was recently manifested $[46,48]$. Moreover, shape-specific 3D scaffolds were constructed from solubilized decellularized tissue by $3 \mathrm{D}$ printing the soluble extracellular matrix components [52].

From the plentiful number of alternatives which exists and can be used to develop complex cellular in vitro models, the use of microfluidics coupled with cocultivation of different cell lineages in a $3 \mathrm{D}$ format represents the state-of-the-art for in vitro models. The above mentioned features are reunited by the so called "organ-on-a-chip" platforms [7]. The first "lungon-a-chip" platform, composed of human alveolar epithelial cells and human pulmonary endothelial cells cultivated on the two different sides of a flexible porous membrane was reported by Huh et al [31]. By incorporating the membrane in-between compartmentalized channels the flow of air and liquid in different compartments allowed the development of an air-liquid interface. Moreover, similarly to the stretch and relax motion present in the respiratory tissue, the developed model mimicked the breathing motion by applying positive and negative pressures in two side channels. Different effects were observed after a bacterial infection and nanoparticle exposure in the dynamic system when compared with the static system, further reiterating the importance of mimicking the physiological conditions in in vitro studies [31]. Similar "lung-on-a-chip" platforms were used to investigate the biological mechanisms behind pulmonary oedema, asthma, COPD and lung cancer. The interest in developing "organ-on-a-chip" has grown continuously since 2012 as they are considered to gradually replace the animal models and other in vitro studies which often lack predictability in drug discovery and testing, thus making drug design cheaper and the drugs more affordable to the population. Additionally, "organon-a-chip" platforms can be coupled in a modular way to create a "body-on-a-chip" platform which can include patient specific differentiated iPSC, holding the promise for the long-awaited personalized medicine [65].

\section{Concluding remarks}

The future of inhalation toxicology lies in the benchmarking of the currently existing in vitro models. Systematic testing in controlled conditions should pinpoint the advantages of these models and ultimately their utility in the evaluation of inhaled toxicants. As currently there is a gap between in vivo and in vitro 
FARMACIA, 2018, Vol. 66, 4

toxicology data, more comparative studies between these complex models and animal models should be performed in order to validate the results obtained with the complex cellular models. Even though an in vitro model which would be able to respond to all questions of interests is still far from being achieved, further improvements of the current models should fill the gap between in vivo and in vitro studies and further allow cheaper, ethically acceptable and high throughput toxicity evaluation.

\section{References}

1. Aggarwal NR, King LS, D'Alessio FR, Diverse macrophage populations mediate acute lung inflammation and resolution. Am J Physiol-Lung C, 2014; 306(8): L709-L725.

2. Alekseeva L, Huet D, Féménia F, Mouyna I, Abdelouahab M, Cagna A, Guerrier D, TichannéSeltzer V, Baeza-Squiban A, Chermette R, Inducible expression of beta defensins by human respiratory epithelial cells exposed to Aspergillus fumigatus organisms. Bmc Microbiol., 2009; 9(1): 1-21.

3. Alfaro-Moreno E, Nawrot TS, Vanaudenaerde BM, Hoylaerts MF, Vanoirbeek JA, Nemery B, Hoet PH, Co-cultures of multiple cell types mimic pulmonary cell communication in response to urban PM10. Eur Respir J., 2008; 32: 1184-1194.

4. Atsuta J, Sterbinsky SA, Plitt J, Schwiebert LM, Bochner BS, Schleimer RP, Phenotyping and cytokine regulation of the BEAS-2B human bronchial epithelial cell: demonstration of inducible expression of the adhesion molecules VCAM-1 and ICAM-1. Am J Resp Cell Mol., 1997; 17(5): 571-582.

5. Bai S, Yang T, Abbruscato TJ, Ahsan F, Evaluation of human nasal RPMI 2650 cells grown at an airliquid interface as a model for nasal drug transport studies. J Pharm Sci., 2008; 97(3): 1165-1178.

6. Bengalli R, Mantecca P, Camatini M, Gualtieri M, Effect of nanoparticles and environmental particles on a cocultures model of the air-blood barrier. Biomed Res Int., 2013; 2013: 1-9.

7. Bhatia SN, Ingber DE, Microfluidic organs-on-chips. Nat Biotechnol., 2014; 32(8): 760-772.

8. Butler CR, Hynds RE, Gowers KHC, Lee DD, Brown JM, Crowley C, Teixeira VH, Smith CM, Urbani L, Hamilton NJ, Rapid expansion of human epithelial stem cells suitable for airway tissue engineering. Am J Resp Crit Care, 2016; 194(2): 156-168.

9. Castell JV, Gomez-Lechon MJ, Donato MT, Metabolism and bioactivation of toxicants in the lung. The in vitro cellular approach. Exp Toxicol Pathol., 2005; 57: 189-204.

10. Chowdhury F, Howat WJ, Phillips GJ, Lackie PM, Interactions between endothelial cells and epithelial cells in a combined cell model of airway mucosa: effects on tight junction permeability. Exp Lung Res., 2010; 36(1): 1-11.

11. Chvatal A, Alzhrani R, Tiwari AK, Ambrus R, SzaboRevesz P, Boddu S, Cytotoxicity of inhalable dry powders in A549 human lung cancer cell line. Farmacia, 2018; 66(1): 172-175.
12. Comer DM, Elborn JS, Ennis M, Comparison of nasal and bronchial epithelial cells obtained from patients with COPD. PloS One, 2012; 7(3): 1-8.

13. Cooper JR, Abdullatif MB, Burnett EC, Kempsell KE, Conforti F, Tolley H, Collins JE, Long Term Culture of the A549 cancer cell line promotes multilamellar body formation and differentiation towards an alveolar type II pneumocyte phenotype. PloS One, 2016; 11(10): 1-20.

14. Courcot E, Leclerc J, Lafitte JJ, Mensier E, Jaillard S, Gosset P, Shirali P, Pottier N, Broly F, Lo-Guidice $\mathrm{JM}$, Xenobiotic metabolism and disposition in human lung cell models: comparison with in vivo expression profiles. Drug Metab Dispos., 2012; 40(10): 1953-1965.

15. Dehai C, Bo P, Qiang T, Lihua S, Fang L, Shi J, Jingyan C, Yan Y, Guangbin W, Zhenjun Y, Enhanced invasion of lung adenocarcinoma cells after coculture with THP-1-derived macrophages via the induction of EMT by IL-6. Immunol Lett., 2014; 160(1): 1-10.

16. Endter S, Francombe D, Ehrhardt C, Gumbleton M, RT PCR analysis of ABC, SLC and SLCO drug transporters in human lung epithelial cell models. $J$ Pharm Pharmacol., 2009; 61(5): 583-591.

17. Fierascu I, Ungureanu C, Avramescu SM, Cimpeanu C, Georgescu MI, Fierascu RC, Ortan A, Sutan AN, Anuta V, Zanfirescu A, Dinu-Pirvu CE, Velescu BS, Genoprotective, antioxidant, antifungal and antiinflammatory evaluation of hydroalcoholic extract of wild-growing Juniperus communis L. (Cupressaceae) native to Romanian southern sub-Carpathian hills. BMC Complement Altern Med., 2018;18(1):3: 1-14.

18. Fehrenbach H, Alveolar epithelial type II cell: defender of the alveolus revisited. Resp Res., 2001; 2(1): 33-46.

19. Fröhlich E, Meindl C, In vitro assessment of chronic nanoparticle effects on respiratory cells. In: Nanomaterials-Toxicity and Risk Assessment. InTech, Rijeka, 2015: 69-91.

20. Gazdar AF, Linnoila RI, Kurita Y, Oie HK, Mulshine JL, Clark JC, Whitsett JA, Peripheral airway cell differentiation in human lung cancer cell lines. Cancer Res., 1990; 50(17): 5481-5487.

21. Gonçalves VS, Matias AA, Poejo J, Serra AT, Duarte CM, Application of RPMI 2650 as a cell model to evaluate solid formulations for intranasal delivery of drugs. Int J Pharm., 2016; 515(1): 1-10.

22. Grainger CI, Greenwell LL, Lockley DJ, Martin GP, Forbes B, Culture of Calu-3 cells at the air interface provides a representative model of the airway epithelial barrier. Pharm Res., 2006; 23(7): 1482-1490.

23. Halamoda Kenzaoui B, Angeloni S, Overstolz T, Niedermann P, Chapuis Bernasconi C, Liley M, Juillerat-Jeanneret L, Transfer of ultrasmall iron oxide nanoparticles from human brain-derived endothelial cells to human glioblastoma cells. Acs Appl Mater Inter., 2013; 5(9): 3581-3586.

24. Hasenberg M, Stegemann Koniszewski S, Gunzer $\mathrm{M}$, Cellular immune reactions in the lung. Immunol Rev., 2013; 251(1): 189-214.

25. Heijink I, van Oosterhout A, Kliphuis N, Jonker M, Hoffmann R, Telenga E, Klooster K, Slebos DJ, ten Hacken N, Postma D, van den Berge M, Oxidant- 
FARMACIA, 2018, Vol. 66, 4

induced corticosteroid unresponsiveness in human bronchial epithelial cells. Thorax, 2014; 69(1): 5-13.

26. Hermanns MI, Kasper J, Dubruel P, Pohl C, Uboldi C, Vermeersch V, Fuchs S, Unger RE, Kirkpatrick CJ, An impaired alveolar-capillary barrier in vitro: effect of proinflammatory cytokines and consequences on nanocarrier interaction. $J R$ Soc Interface, 2010; 7(Supp11): S41-S54.

27. Hermanns MI, Unger RE, Kehe K, Peters K, Kirkpatrick CJ, Lung epithelial cell lines in coculture with human pulmonary microvascular endothelial cells: development of an alveolo-capillary barrier in vitro. Lab Invest, 2004; 84(6): 736-752.

28. Hiemstra PS, McCray PB, Bals R, The innate immune function of airway epithelial cells in inflammatory lung disease. Eur Respir J., 2015; 45(4): 1150-1162.

29. Hirakata Y, Yano H, Arai K, Endo S, Kanamori H, Aoyagi T, Hirotani A, Kitagawa M, Hatta M, Yamamoto $\mathrm{N}$, Kunishima $\mathrm{H}$, Monolayer culture systems with respiratory epithelial cells for evaluation of bacterial invasiveness. Tohoku J Exp Med., 2010; 220(1): 15-19.

30. Horani A, Nath A, Wasserman MG, Huang T, Brody SL, Rho-associated protein kinase inhibition enhances airway epithelial Basal-cell proliferation and lentivirus transduction. Am J Resp Cell Mol., 2013; 49(3): 341-347.

31. Huh D, Matthews BD, Mammoto A, Montoya-Zavala M, Hsin HY, Ingber DE, Reconstituting organ-level lung functions on a chip. Science, 2010; 328(5986): $1662-1668$.

32. Jantzen K, Roursgaard M, Desler C, Loft S, Rasmussen LJ, Møller P, Oxidative damage to DNA by diesel exhaust particle exposure in co-cultures of human lung epithelial cells and macrophages. Mutagenesis, 2012; 27(6): 693-701.

33. Kasper JY, Hermanns MI, Unger RE, Kirkpatrick $\mathrm{CJ}$, A responsive human triple culture model of the air-blood barrier: incorporation of different macrophage phenotypes. J Tissue Eng Regen M., 2017; 11(4): 1285-1297.

34. Kingma PS, Whitsett JA, In defense of the lung: surfactant protein A and surfactant protein D. Curr Opin Pharmacol., 2006; 6(3): 277-283.

35. Kinnula VL, Yankaskas JR, Chang L, Virtanen I, Linnala A, Kang BH, Primary and immortalized (BEAS 2B) human bronchial epithelial cells have significant antioxidative capacity in vitro. $\mathrm{Am} \mathrm{J}$ Resp Cell Mol., 1994; 11(5): 568-576.

36. Klein SG, Serchi T, Hoffmann L, Blömeke B, Gutleb AC, An improved 3D tetraculture system mimicking the cellular organisation at the alveolar barrier to study the potential toxic effects of particles on the lung. Part Fibre Toxicol., 2013; 10(1): 1-17.

37. Klein SG, Cambier S, Hennen J, Legay S, Serchi T, Nelissen I, Chary A, Moschini E, Krein A, Blömeke $\mathrm{B}$, Endothelial responses of the alveolar barrier in vitro in a dose-controlled exposure to diesel exhaust particulate matter. Part Fibre Toxicol., 2017; 14(1): $1-17$.

38. Klein SG, Hennen J, Serchi T, Blomeke B, Gutleb $\mathrm{AC}$, Potential of coculture in vitro models to study inflammatory and sensitizing effects of particles on the lung. Toxicol in vitro, 2011; 25: 1516-1534.
39. Krapf M, Künzi L, Allenbach S, Bruns EA, Gavarini I, El-Haddad I, Slowik JG, Prévôt AS, Drinovec L, Močnik G, Dümbgen L, Wood combustion particles induce adverse effects to normal and diseased airway epithelia. Environ Sci-Proc Imp., 2017; 19(4): 538-548.

40. Kreft ME, Jerman UD, Lasič E, Rižner TL, HevirKene N, Peternel L, Kristan K, The characterization of the human nasal epithelial cell line RPMI 2650 under different culture conditions and their optimization for an appropriate in vitro nasal model. Pharm Res., 2015; 32(2): 665-679.

41. Kürti L, Veszelka S, Bocsik A, Ózsvári B, Puskás LG, Kittel Á, Szabó-Révész P, Deli MA, Retinoic acid and hydrocortisone strengthen the barrier function of human RPMI 2650 cells, a model for nasal epithelial permeability. Cytotechnology, 2013; 65(3): 395-406.

42. Lacroix G, Koch W, Ritter D, Gutleb AC, Larsen ST, Loret T, Zanetti F, Constant S, Chortarea S, Rothen-Rutishauser B, Air-liquid interface in vitro models for respiratory toxicology research: Consensus Workshop and Recommendations. App In Vitro Toxicol., 2018; 4(2): 1-16.

43. Leclercq B, Platel A, Antherieu S, Alleman LY, Hardy EM, Perdrix E, Grova N, Riffault V, Appenzeller BM, Happillon M, Nesslany F, Genetic and epigenetic alterations in normal and sensitive COPD-diseased human bronchial epithelial cells repeatedly exposed to air pollution-derived PM2.5. Environ Pollut., 2017; 230: 163-177.

44. Lehmann AD, Daum N, Bur M, Lehr CM, Gehr P, Rothen-Rutishauser BM, An in vitro triple cell coculture model with primary cells mimicking the human alveolar epithelial barrier. Eur J Pharm Biopharm., 2011; 77(3): 398-406.

45. Luyts K, Napierska D, Dinsdale D, Klein SG, Serchi T, Hoet PH, A coculture model of the lung-blood barrier: the role of activated phagocytic cells. Toxicol In Vitro, 2015; 29(1): 234-241.

46. Melo E, Kasper JY, Unger RE, Farré R, Kirkpatrick CJ, Development of a bronchial wall model: triple culture on a decellularized porcine trachea. Tissue Eng Pt/C-Meth., 2015; 21(9): 909-921.

47. Milara J, Peiró T, Serrano A, Cortijo J, Epithelial to mesenchymal transition is increased in patients with COPD and induced by cigarette smoke. Thorax, 2013; 68: 410-420.

48. Mishra DK, Thrall MJ, Baird BN, Ott HC, Blackmon SH, Kurie JM, Kim MP, Human lung cancer cells grown on acellular rat lung matrix create perfusable tumor nodules. Ann Thorac Surg., 2012; 93(4): 1075-1081.

49. Mizoguchi I, Ohashi M, Chiba Y, Hasegawa H, Xu M, Owaki T, Yoshimoto T, Prediction of chemical respiratory and contact sensitizers by OX401 expression in dendritic cells using a novel 3D coculture system. Front Immunol., 2017; 8: 1-12.

50. Neuhaus W, Samwer F, Kunzmann S, Muellenbach RM, Wirth M, Speer CP, Roewer N, Förster CY, Lung endothelial cells strengthen, but brain endothelial cells weaken barrier properties of a human alveolar epithelium cell culture model. Differentiation, 2012; 84(4): 294-304.

51. Park YH, Kim D, Dai J, Zhang Z, Human bronchial epithelial BEAS-2B cells, an appropriate in vitro 
model to study heavy metals induced carcinogenesis. Toxicol Appl Pharm., 2015; 287(3): 240-245.

52. Pati F, Jang J, Ha DH, Kim SW, Rhie JW, Shim JH, Kim DH, Cho DW, Printing three-dimensional tissue analogues with decellularized extracellular matrix bioink. Nat Commun., 2014; 5: 1-11.

53. Peter HG, Cell culture sheets to study nasal peptide metabolism: The human nasal RPMI 2650 cell line model. Doctoral dissertation, ETH Zurich, 1998.

54. del Pilar Ramos-Godínez M, González-Gómez BE, Montiel-Dávalos A, López-Marure R, Alfaro-Moreno $\mathrm{E}, \mathrm{TiO}_{2}$ nanoparticles induce endothelial cell activation in a pneumocyte-endothelial co-culture model. Toxicol In Vitro, 2013; 27(2): 774-781.

55. Pillai DK, Sankoorikal BJ, Johnson E, Seneviratne AN, Zurko J, Brown KJ, Hathout Y, Rose MC, Directional secretomes reflect polarity-specific functions in an in vitro model of human bronchial epithelium. $\mathrm{Am} \mathrm{J}$ Resp Cell Mol., 2014; 50(2): 292-300.

56. Pirvu L, Sha'at F, Miclea LC, Savopol T, Neagu G, Udeanu DI, Moisescu MG, Polygonum bistorta L. herba et flores. polyphenols profile, antioxidant properties and cytotoxic effect on murine fibroblast cell line NIH3T3. Farmacia, 2017; 65(4): 571-576.

57. Ren H, Birch NP, Suresh V, An optimised human cell culture model for alveolar epithelial transport. PloS One, 2016; 11(10): 1-22.

58. Rubovitch V, Gershnabel S, Kalina M, Lung epithelial cells modulate the inflammatory response of alveolar macrophages. Inflammation, 2007; 30(6): 236-243.

59. Shintani Y, Maruoka S, Gon Y, Koyama D, Yoshida A, Kozu Y, Kuroda K, Takeshita I, Tsuboi E, Soda K, Hashimoto S, Nuclear factor erythroid 2-related factor 2 (Nrf2) regulates airway epithelial barrier integrity. Allergol Int., 2015; 64: S54-S63.

60. Stentebjerg-Andersen A, Notlevsen IV Brodin B., Nielsen CU, Calu-3 cells grown under AIC and LCC conditions: implications for dipeptide uptake and transepithelial transport of substances. Eur $J$ Pharm Biopharm, 2011; 78(1): 19-26.

61. Stewart CE, Torr EE, Jamili M, Nur H, Bosquillon C, Sayers I, Evaluation of differentiated human bronchial epithelial cell culture systems for asthma research. J Allergy, 2012; 2012: 1-11.

62. Swain RJ, Kemp SJ, Goldstraw P, Tetley TD, Stevens MM, Assessment of cell line models of primary human cells by Raman spectral phenotyping. Biophys J., 2010; 98(8): 1703-1711.

63. Takahashi K, Tanabe K, Ohnuki M, Narita M, Ichisaka T, Tomoda K, Yamanaka S, Induction of pluripotent stem cells from adult human fibroblasts by defined factors. Cell, 2007; 131(5): 861-872.

64. Werner U, Kissel T, In-vitro cell culture models of the nasal epithelium: a comparative histochemical investigation of their suitability for drug transport studies. Pharm Res., 1996; 13(7): 978-988.

65. Williamson A, Singh S, Fernekorn U, Schober A, The future of the patient-specific Body-on-a-chip. Lab Chip, 2013; 13(18): 3471-3480.

66. Woodruff PG, Boushey HA, Dolganov GM, Barker CS, Yang YH, Donnelly S, Ellwanger A, Sidhu SS, Dao-Pick TP, Pantoja C, Genome-wide profiling identifies epithelial cell genes associated with asthma and with treatment response to corticosteroids. $P$ Natl Acad Sci USA, 2007; 104(40): 15858-15863.

67. Wottrich R, Diabaté S, Krug HF, Biological effects of ultrafine model particles in human macrophages and epithelial cells in mono-and co-culture. Int $J$ Hyg Envir Heal., 2004; 207(4): 353-361.

68. Xiao C, Puddicombe SM, Field S, Haywood J, Broughton-Head V, Puxeddu I, Haitchi HM, VernonWilson E, Sammut D, Bedke N, Cremin C, Defective epithelial barrier function in asthma. $J$ Allergy Clin Immun, 2011; 128(3): 549-556.

69. Yang L, Wang WC, Lung SC, Sun Z, Chen C, Chen $\mathrm{JK}$, Zou Q, Lin YH, Lin CH, Polycyclic aromatic hydrocarbons are associated with increased risk of chronic obstructive pulmonary disease during haze events in China. Sci Total Environ., 2017; 574: 1649-1658.

70. Zhu J, Rogers AV, Burke Gaffney A, Hellewell PG, Jeffery PK, Cytokine induced airway epithelial ICAM 1 upregulation: quantification by high resolution scanning and transmission electron microscopy. Eur Respir J., 1999; 13(6): 1318-1328. 